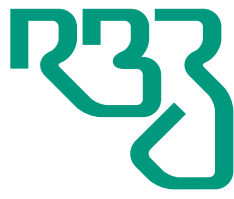

Revista

Brasileira de

Zootecnia

Brazilian Journal of Animal Science

ISSN 1806-9290

www.rbz.org.br

\title{
Cooling of curimba (Prochilodus lineatus) embryos using different concentrations of dimethyl sulphoxide and methanol
}

\author{
Gilmara Junqueira Machado ${ }^{1}$ (iD), Luis David Solis Murgas $^{1^{*}}$ (iD), Priscila \\ Cotta Palhares $^{2}$, Isadora de Lima Assis ${ }^{1}$ (iD), Tássia Flávia Dias Castro ${ }^{1}$ (iD \\ ${ }^{1}$ Universidade Federal de Lavras, Departamento de Medicina Veterinária, Lavras, MG, Brasil. \\ ${ }^{2}$ Instituto Federal de Educação, Ciência e Tecnologia do Sudeste de Minas Gerais, Rio \\ Pomba, MG, Brasil.
}

\author{
*Corresponding author: \\ lsmurgas@ufla.br \\ Received: January 24, 2017 \\ Accepted: May 17, 2019 \\ How to cite: Machado, G. J.; Murgas, L. D. S.; \\ Palhares, P. C.; Assis, I. L. and Castro, T. F. D. \\ 2019. Cooling of curimba (Prochilodus lineatus) \\ embryos using different concentrations of \\ dimethyl sulphoxide and methanol. Revista \\ Brasileira de Zootecnia 48:e20160377. \\ https://doi.org/10.1590/rbz4820160377 \\ Copyright: This is an open access article \\ distributed under the terms of the \\ Creative Commons Attribution License \\ (http://creativecommons.org/licenses/by/4.0/), \\ which permits unrestricted use, distribution, \\ and reproduction in any medium, provided the \\ original work is properly cited.
}

ABSTRACT - This study aimed to evaluate the effect of using different concentrations $(5,7.5,10$, and $12.5 \%)$ of two permeating cryoprotectants, dimethyl sulphoxide (DMSO) and methanol, on Prochilodus lineatus embryos while being subjected to cooling for 2 , 4,6 , and $8 \mathrm{~h}$ at $4{ }^{\circ} \mathrm{C}$. We analyzed the hatching rate, viable larvae, and counts of hatched and spoiled eggs and those that did not complete their development after cooling. We observed a significant interaction among variables, permeable cryoprotectant concentration, and cooling time, having the increase of these factors caused a reduction in hatching rate. The curimba embryos showed a higher sensitivity to cold at a temperature of $4{ }^{\circ} \mathrm{C}$ for 6 and $8 \mathrm{~h}$, directly influencing the production of viable larvae. We did not observe a significant difference in the variables analyzed when comparing the cryoprotectant solutions containing DMSO, methanol, and solutions containing only water and sucrose $(0.5 \mathrm{M})$. An increase in the concentration of cryoprotectant and cooling time promotes a reduction in the hatching rate and in the percentage of viable curimba larvae.

Keywords: aquaculture, biotechnology, cryopreservation, eggs, fish, larvae

\section{Introduction}

The curimba species belongs to the Prochilodontidae family and has a wide distribution in the basins of South America (Reis et al., 2003), with both ecological and commercial importance. It is characterized by fast embryonic development, non-adhesive eggs, a large perivitelline space, and a large yolk, all of which are necessary characteristics for use as a biological model for cryopreservation studies (Rizzo et al., 2003; Ninhaus-Silveira, 2007).

The use of biotechnology for gamete cryopreservation has been successfully applied to prolong the viability of gametes, mainly using refrigeration and freezing techniques (Zaniboni-Filho and Baldisserotto, 2015). These technologies could provide new perspectives in the cultivation and management of endangered species, such as provide greater viability of gametes and embryos, as well as enabling the deployment and consolidation of genetic material banks. In addition, these techniques could provide embryos for some species in periods when natural spawning does not occur, allowing for an increase in commercial production and conservation.

Cooling consists of maintaining the eggs at low temperatures, but above the freezing point, which reduces metabolic activity, thus prolonging their viability in the external environment. This process 
has been used as a strategy for conservation and maintenance of gametes for limited time frames of a few hours or even for several days (Paes, 2013; Paula et al., 2014). Embryos are subjected to low temperatures for a specific time, as a way of preserving them during transport to remote sites, such as when they are taken to a laboratory for incubation (Ahammad et al., 2003). In this respect, cooling appears to be a viable alternative for short-term preservation. However, the success of the procedure is variable and depends on the species and use of specific cryoprotectants.

Cryoprotectant substances are considered to have a key role in the cryopreservation process, but it is necessary to determine both the type and ideal concentration necessary to prevent possible embryo damage by exposure to low temperatures (Costa et al., 2018). The fundamental characteristics for an effective permeating cryoprotective agent are low molecular weight, high capacity to cross the cell membrane, and low toxicity. In general, agents with rapid penetration capacity are more efficient because the time of exposure to the cryoprotectant before cooling is shorter, preventing osmotic injuries (Costa et al., 2017).

Cooling and embryo freezing techniques, as well as cryoprotectant toxicity tests, have been studied in several species of native fish, in both species of economic interest and those endangered; some of the studied species are Piaractus mesopotamicus (Lopes et al., 2014), Piaractus brachypomus (Pessoa et al., 2015), Brycon orbignyanus (Fornari et al., 2014; Paes et al., 2014), and Prochilodus lineatus (Paula et al., 2014; Costa et al., 2017). Studies with ornamental fish species, such as Danio rerio, have also been conducted (Henn and Braunbeck, 2011; Kais et al., 2013).

This study aimed to evaluate the effect of using different concentrations of dimethyl sulphoxide (DMSO) and methanol on Prochilodus lineatus embryos while being subjected to cooling for 2, 4, 6, and $8 \mathrm{~h}$ at $4{ }^{\circ} \mathrm{C}$.

\section{Material and Methods}

The experiments were conducted in the breeding laboratory of a fish farm in Itutinga, Minas Gerais, Brazil (211' $\left.25.46^{\prime \prime} ; 44^{\circ} 36^{\prime} 58.59^{\prime \prime}\right)$, during the months of November, December, and January, 2009 to 2010. All experimental procedures were performed in accordance with the ethical principles for animal experimentation (case no. 0336/2009).

Five curimba pairs were selected from the broodstock of the environmental station. The breeders were selected according to the reproductive characteristics cited by Woynarovich and Horváth (1989) and Murgas et al. (2012). Mature males were those able to release a few drops of semen under mild abdominal massage. Females suitable for the hormonal induction of spawning showed a developed abdomen soft to the touch, prominent urogenital papilla with pink or red color, and a slightly open genital orifice.

After selection, breeders were individually weighed to calculate the appropriate hormone dose. We administered $1.0 \mathrm{~mL} \mathrm{~kg}^{-1}$ of buserelin acetate in two divided doses ( 25 and $75 \%$ ) by intramuscular injection at the base of the dorsal fin, for both sexes. Then, breeders were placed in masonry tanks with a capacity of $2000 \mathrm{~L}$, with controlled temperature $\left(28^{\circ} \mathrm{C}\right)$ and continuous water renewal.

Spawning occurred between 8 and $9 \mathrm{~h}$ after the second hormonal application; the urogenital papilla and anal fin were wiped with paper towels, avoiding contact of the gametes with water. The gametes were obtained through manual massages of the coelomic wall in the craniocaudal direction.

The spawn of each female was held in a previously cleaned, dry plastic container. The semen of each male was used for the fertilization of each female, thus forming different pairs. We then added water and mixed the gametes through mild agitation, performing consecutive water exchanges for better activation and subsequent fertilization of oocytes. After fertilization, the eggs were placed in 200-L conic incubators, with continuous water flow and controlled temperature $\left(27^{\circ} \mathrm{C}\right)$.

When $80 \%$ of the eggs were at the blastopore closing stage with $90 \%$ epibolia (about $9 \mathrm{~h}$ of incubation), they were observed in a stereo microscope; a sample of viable eggs was collected from the incubator and the foiled eggs were discarded. After draining the excess water with a small plastic sieve, an average 
of $100 \pm 10$ embryos were collected and placed in plastic cups with $20 \mathrm{~mL}$ of the tested cryoprotectant solutions, namely: water; $0.5 \mathrm{M}$ sucrose; $5 \%$ DMSO + $0.5 \mathrm{M}$ sucrose; $7.5 \%$ DMSO $+0.5 \mathrm{M}$ sucrose; $10 \%$ DMSO + $0.5 \mathrm{M}$ sucrose; $12.5 \%$ DMSO $+0.5 \mathrm{M}$ sucrose; $5 \%$ methanol $+0.5 \mathrm{M}$ sucrose; $7.5 \%$ methanol + $0.5 \mathrm{M}$ sucrose; $10 \%$ methanol $+0.5 \mathrm{M}$ sucrose; and $12.5 \%$ methanol $+0.5 \mathrm{M}$ sucrose.

Plastic cups containing the embryos were taken to the refrigerator $\left(4^{\circ} \mathrm{C}\right)$. After the determined cooling times $(2,4,6$, and $8 \mathrm{~h})$, embryos from each treatment were removed, the cryoprotectant solution was drained, and the embryos were immediately taken to the 1-L experimental incubators (Paula et al., 2014) to complete their development. From the time of egg hatching, we established a 16-18 hpf (hours post fertilization) period for the evaluation of embryos and larvae. The assessment consisted of defining the number of fertilized eggs and hatched viable larvae. Viable larvae were considered as those showing linear body structure, notochord extending linearly through the body, presence of a well-defined optic vesicle, and yolk sac with an organized appearance, without abnormal vesicles, according to Costa et al. (2017).

Hatching rate $=[$ number of larvae $/$ number of incubated eggs $] \times 100$

The experimental design was completely randomized in a $2 \times 4 \times 4$ factorial $(n=5)$, with two permeating cryoprotectants (methanol and DMSO) at four concentrations $(5,7.5,10$, and $12.5 \%)$ with the addition of $0.5 \mathrm{M}$ sucrose as a non-permeating cryoprotectant, exposed to four cooling times $(2,4,6$, and $8 \mathrm{~h})$. In addition, there were two additional $2 \times 4$ control treatments $(n=5)$, one containing $0.5 \mathrm{M}$ sucrose and one containing water only, which were also exposed to four storage times $(2,4,6$, and $8 \mathrm{~h})$. In total, 40 treatments were tested in five repetitions, and each treatment was conducted independently, with the pair considered as the experimental unit.

Analyses were performed using Minitab 17 statistical software. Normality was tested using a Shapiro-Wilk test. Variance was analyzed using the ANOVA procedure for a full factorial design, and pairwise comparisons (95\%) for the cryoprotectant solutions, concentration, and cooling time were tested. The possible interactions among cryoprotectant solutions, concentration, cooling time, and their independent effect were evaluated through regression analysis.

\section{Results}

No significant difference was observed among the cryoprotectants solutions tested, DMSO, methanol, water, and $0.5 \mathrm{M}$ sucrose $(\mathrm{P}>0.05)$ (Table 1$)$. There was an interaction between cryoprotectant

Table 1 - Hatching rates (mean \pm standard deviation) of curimba embryos subjected to cryoprotectant solutions containing different concentrations of dimethyl sulphoxide (DMSO) and methanol, exposed to four cooling times at $4{ }^{\circ} \mathrm{C}$

\begin{tabular}{lcccc}
\hline \multirow{2}{*}{ Cryoprotectant solution } & \multicolumn{4}{c}{ Hatching rate (\%) } \\
\cline { 2 - 5 } & $2 \mathrm{~h}$ & $4 \mathrm{~h}$ & $6 \mathrm{~h}$ & \\
\hline C1 & $97.82 \pm 1.68 \mathrm{a}$ & $95.04 \pm 8.50 \mathrm{a}$ & $74.94 \pm 42.51 \mathrm{~b}$ & $55.95 \pm 37.69 \mathrm{c}$ \\
C2 & $96.66 \pm 4.24 \mathrm{a}$ & $99.39 \pm 1.36 \mathrm{a}$ & $77.48 \pm 43.47 \mathrm{~b}$ & $76.39 \pm 43.08 \mathrm{~b}$ \\
D1 & $97.03 \pm 3.60$ & $93.56 \pm 5.83$ & $82.79 \pm 32.52$ & $75.81 \pm 42.54$ \\
D2 & $96.72 \pm 3.74$ & $95.04 \pm 6.31$ & $77.24 \pm 43.20$ & $64.43 \pm 38.09$ \\
D3 & $96.57 \pm 4.03$ & $90.14 \pm 15.61$ & $73.20 \pm 41.75$ & $41.84 \pm 46.50$ \\
D4 & $95.43 \pm 6.73$ & $81.90 \pm 26.04$ & $49.49 \pm 36.51$ & $18.16 \pm 39.22$ \\
M1 & $98.69 \pm 1.40$ & $96.52 \pm 6.19$ & $89.92 \pm 14.90$ & $77.41 \pm 43.38$ \\
M2 & $95.09 \pm 9.43$ & $95.09 \pm 6.04$ & $94.66 \pm 8.22$ & $57.63 \pm 46.27$ \\
M3 & $97.94 \pm 2.53$ & $95.97 \pm 2.75$ & $80.85 \pm 33.64$ & $39.45 \pm 42.62$ \\
M4 & $95.93 \pm 2.93$ & $93.25 \pm 9.66$ & $63.97 \pm 37.72$ & $53.58 \pm 45.62$ \\
\hline
\end{tabular}

C1 - water; C2 - 0.5M sucrose; D1 - 5\% DMSO + 0.5M sucrose: D2 - 7.5\% DMSO + 0.5M sucrose; D3 - 10\% DMSO + 0.5M sucrose; D4 - 12.5\% DMSO + 0.5M sucrose; M1 - 5\% methanol + 0.5M sucrose; M2 - 7.5\% methanol + $0.5 \mathrm{M}$ sucrose; M3 - $10 \%$ methanol + $0.5 \mathrm{M}$ sucrose; M4 - $12.5 \%$ methanol + $0.5 \mathrm{M}$ sucrose.

Lowercase letters in rows differ by pairwise comparisons $(\mathrm{P}<0.05)$ 
concentration and cooling time $(\mathrm{P}<0.05)$, as the increase of these factors caused a significant reduction in the hatching rate of curimba embryos (Figure 1). Both methanol and DMSO solutions led to hatching rates above $90 \%$ when embryos were kept for $4 \mathrm{~h}$ at $4{ }^{\circ} \mathrm{C}$. When the cooling time was increased to 6 and $8 \mathrm{~h}$, we observed a reduction in hatching rate, which was also observed for the water and $0.5 \mathrm{M}$ sucrose treatments (Table 1).

When the percentage of viable hatchlings was evaluated, no interaction was observed between the variables. The percentage of viable larvae was not significantly different $(\mathrm{P}>0.05)$ among the cryoprotectant solutions and water and $0.5 \mathrm{M}$ sucrose treatments (Table 2). However, there was a linear decline in the percentage of viable larvae with an increase in the concentration for both cryoprotectants and cooling time (Figures 2 and 3). The high concentrations of both DMSO and methanol and longer exposure times at $4{ }^{\circ} \mathrm{C}$, for all solutions tested, including solutions containing only water and $0.5 \mathrm{M}$ sucrose (Table 2), promoted a negative effect on hatching of viable larvae.
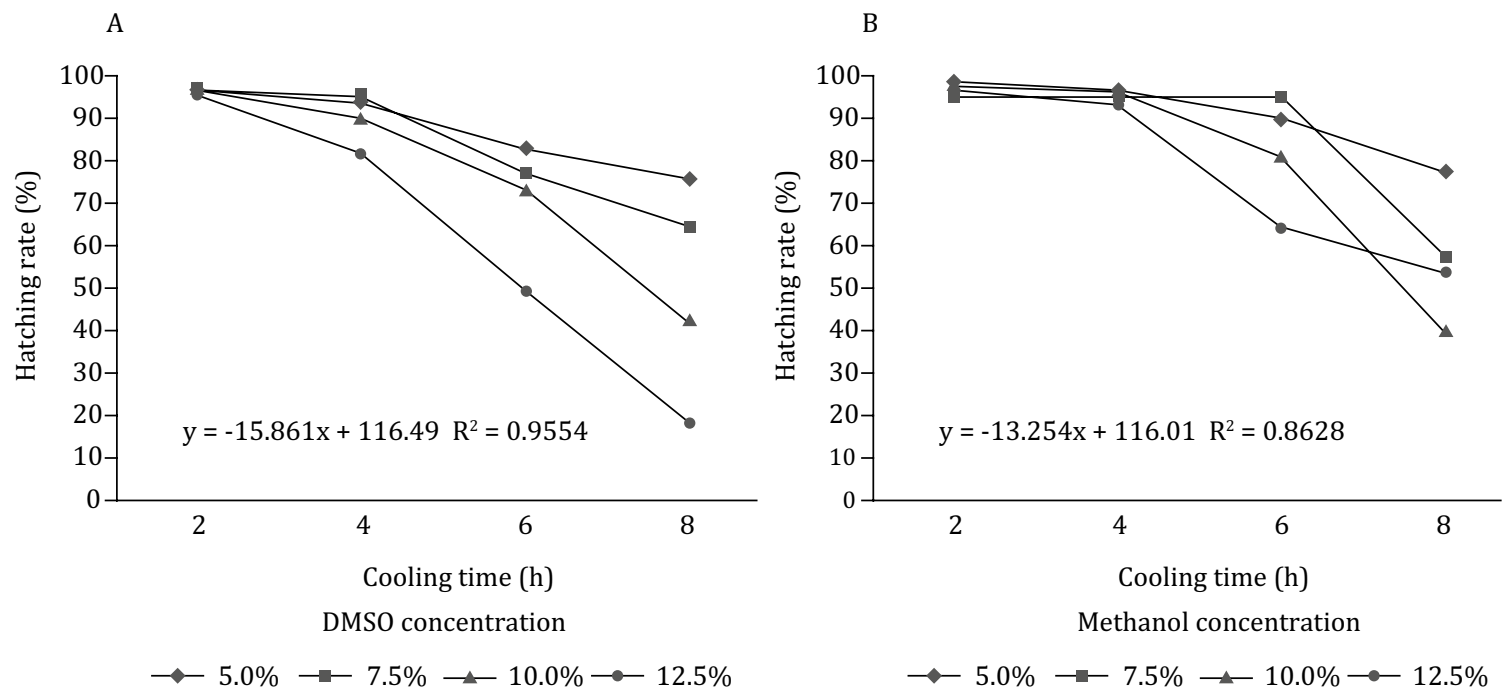

Figure 1 - Linear regression of the interaction between cooling time at $4{ }^{\circ} \mathrm{C}$ and concentration of dimethyl sulphoxide (DMSO; A) and methanol (B) on hatching rates of curimba embryos.

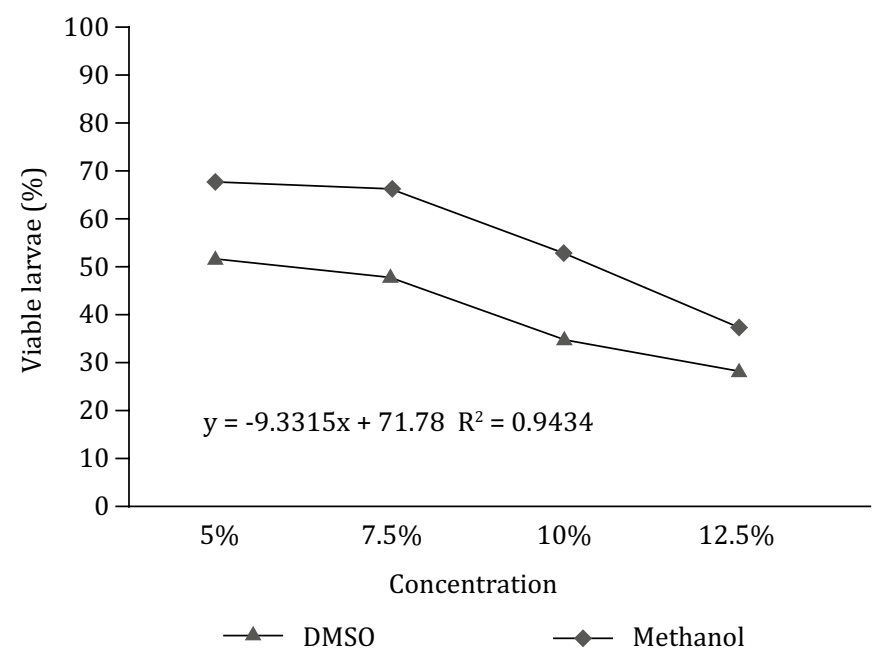

Figure 2 - Linear regression of the effect of concentration of dimethyl sulphoxide (DMSO) and methanol on percentage of viable curimba larvae of embryos cooled at $4{ }^{\circ} \mathrm{C}$. 


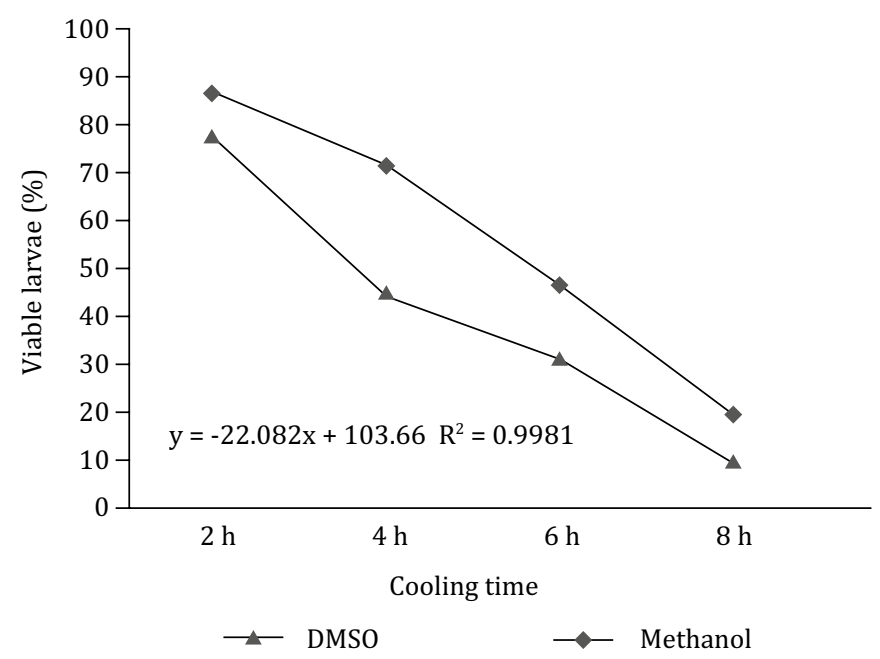

Figure 3 - Linear regression of the effect of cooling time on percentage of viable curimba larvae of embryos cooled at $4{ }^{\circ} \mathrm{C}$.

Table 2 - Viable larvae (mean \pm standard deviation) of curimba embryos subjected to cryoprotectant solutions containing different concentrations of dimethyl sulphoxide (DMSO) and methanol, exposed to four cooling times at $4{ }^{\circ} \mathrm{C}$

\begin{tabular}{lcccc}
\hline \multirow{2}{*}{ Cryoprotectant solution } & \multicolumn{4}{c}{ Viable larvae (\%) } \\
\cline { 2 - 5 } & $2 \mathrm{~h}$ & $4 \mathrm{~h}$ & $6 \mathrm{~h}$ & $8 \mathrm{~h}$ \\
\hline C1 & $82.01 \pm 15.40 \mathrm{a}$ & $58.10 \pm 46.38 \mathrm{~b}$ & $50.13 \pm 44.07 \mathrm{c}$ & $13.00 \pm 16.71 \mathrm{~d}$ \\
C2 & $87.11 \pm 14.70 \mathrm{a}$ & $56.14 \pm 47.93 \mathrm{~b}$ & $52.63 \pm 48.71 \mathrm{c}$ & $29.46 \pm 38.40 \mathrm{~d}$ \\
D1 & $87.65 \pm 15.90$ & $52.66 \pm 42.46$ & $42.82 \pm 42.87$ & $23.66 \pm 27.85$ \\
D2 & $79.89 \pm 24.75$ & $68.83 \pm 34.48$ & $31.04 \pm 44.95$ & $12.62 \pm 20.28$ \\
D3 & $71.41 \pm 32.50$ & $39.59 \pm 44.03$ & $26.82 \pm 38.86$ & $2.20 \pm 3.37$ \\
D4 & $71.29 \pm 24.34$ & $23.83 \pm 35.51$ & $17.23 \pm 35.29$ & $1.06 \pm 2.38$ \\
$*$ & & & \\
M1 & $87.45 \pm 13.52$ & $76.98 \pm 29.94$ & $65.34 \pm 39.63$ & $40.99 \pm 46.98$ \\
M2 & $84.93 \pm 19.76$ & $79.20 \pm 14.15$ & $69.53 \pm 32.03$ & $31.26 \pm 29.14$ \\
M3 & $88.03 \pm 6.91$ & $75.21 \pm 19.47$ & $45.42 \pm 31.83$ & $3.02 \pm 6.75$ \\
M4 & $85.65 \pm 10.02$ & $54.82 \pm 12.42$ & $6.21 \pm 8.94$ & $3.81 \pm 5.22$ \\
$* *$ & & & & \\
\hline
\end{tabular}

C1 - water; C2 - 0.5M sucrose; D1 - 5\% DMSO + 0.5M sucrose: D2 - 7.5\% DMSO + 0.5M sucrose; D3 - 10\% DMSO + 0.5M sucrose; D4 - 12.5\% DMSO + 0.5M sucrose; M1 - 5\% methanol + 0.5M sucrose; M2 - 7.5\% methanol + 0.5M sucrose; M3 - 10\% methanol + 0.5M sucrose; M4 - $12.5 \%$ methanol $+0.5 \mathrm{M}$ sucrose.

Lowercase letters in rows differ, and * or ** differ in cryoprotectant, by pairwise comparisons $(\mathrm{P}<0.05)$.

\section{Discussion}

Zhang et al. (2005) tested concentrations of cryoprotectants for Paralichthys olivaceus embryo cryopreservation: the lowest concentrations showed the lowest toxicity and the highest percentage of embryo survival. Similarly, in this study, lower concentrations of cryoprotectants also showed significantly better results for cryopreservation. The lowest concentrations of methanol and DMSO resulted in similar hatching rates, superior to $90 \%$, which is considered as a great rate for curimba. Urbányi et al. (1997) also obtained a hatching rate of $90 \%$ after exposure of Cyprinus carpio embryos to $3.2 \%$ methanol (1M); this result differed from that observed by Ahammad et al. (2003), who found a hatching rate of $74 \%$ using $4.8 \%$ methanol for rohu (Labeu rohita). 
Hubálek (2003) considered a concentration of $10 \%$ methanol as an ideal composition for the conservation solution of microorganisms. Similarly, several studies used concentrations of $9-10 \%$ methanol for fish embryos of species such as Rhinelepis aspera (Fornari et al., 2008), Colossoma macropomum (Pessoa et al., 2013), Brycon obignyanus (Fornari et al., 2014; Paes et al., 2014), Piaractus mesopotamicus (Lopes et al., 2014), and Piaractus brachypomus (Pessoa et al., 2015). In this study, we obtained an $80.85 \%$ hatching rate with $10 \%$ methanol for $6 \mathrm{~h}$ of cooling, and Pessoa et al. (2013) observed an $88 \%$ hatching rate of Colossoma macropomum embryos treated with a $10 \%$ methanol solution. However, other authors observed lower values in different species. For example, Ahammad et al. (2003) observed a 48\% hatching rate for Labeu rohita, using $9.6 \%$ methanol; Streit Jr. et al. (2007) obtained hatching rates of 61.22 and 56.52\% for DMSO and methanol, respectively, both at a concentration of $10 \%$ for pacu (Piaractus mesopotamicus) embryos. For curimba, $10 \%$ DMSO and $6 \mathrm{~h}$ cooling led to a $77.24 \%$ hatching rate.

In general, the use of a combination of permeating and non-permeating cryoprotectant solutions for cooling fish embryos is recommended, since it allows for an increase in hatching rates of the embryos (Costa et al., 2017). Fornari et al. (2008) obtained a 0\% hatching rate for Rhinelepis aspera embryos, using only water and cooling at $-8{ }^{\circ} \mathrm{C}$ for $6 \mathrm{~h}$. Inversely, Streit Jr. et al. (2007) concluded that Piaractus mesopotamicus embryos can withstand temperatures of up to $-7^{\circ} \mathrm{C}$ for $4 \mathrm{~h}$ without the presence of any cryoprotectant solution. These results were also observed in this study, in which the treatment containing only water had similar hatching rates to the other tested solutions, at $4{ }^{\circ} \mathrm{C}$ for $4 \mathrm{~h}$. The embryos of different species of fish may be more or less sensitive to cooling temperature, and the structure of the embryo may have a greater permeability to certain substances.

Cryoprotectants are essential to the process of cooling and freezing, but these agents may cause cell mortality (Chao and Liao, 2001). An increase in concentration of cryoprotectant solutions maximized toxicity, because hatching rate and percentage of viable larvae decreased. Cabrita et al. (2003) stated that the effect of each cryoprotectant does not only depend on its chemical properties, but also on embryo species, having shown different results when comparing the action of cryoprotectants in different fish species. Paula et al. (2014) and Costa et al. (2017) observed that cryoprotectant solutions promote numerous morphological lesions, compromising normal embryonic development.

In this study, we did not observe significant difference between cryoprotectant solutions containing DMSO and methanol; however, cooling time caused a reduction in hatching rate of curimba embryos. Excessive exposure time to the cryoprotectant solution, according to Bart and Kyaw (2003) and Costa et al. (2017), may potentiate the toxic effect of the cryoprotectant agent on the embryo. Pessoa et al. (2013) and Paes (2013) tested different cooling times on Colossoma macropomum and Brycon orbignyanus embryos and observed a significant decrease in the number of larvae as the storage time increased. Streit Jr. (2007) showed that Piaractus mesopotamicus embryos have a higher sensitivity to cold at a temperature of $-7^{\circ} \mathrm{C}$, for $6 \mathrm{~h}$, presenting 13.9 and $47.4 \%$ of the embryos hatching to DMSO and methanol, respectively. Curimba embryos also showed a higher sensitivity to cold at a temperature of $4{ }^{\circ} \mathrm{C}$ for 6 and $8 \mathrm{~h}$.

Solutions that use methanol as the permeating cryoprotectant lead to a higher percentage of viable larvae compared with those in which the permeating cryoprotectant is DMSO. However, this fact was not proven in this study. The efficiency of the permeating cryoprotectant is related to the narrow equilibrium, low toxicity, and high permeability of the cryoprotectant in the embryo. The use of methanol as a cryoprotectant has also shown satisfactory results because of its low toxicity and good permeability in the cell membrane (Hagedorn et al., 1997; Costa et al., 2017). The positive effects of methanol as a cryoprotectant for fish embryos has been observed in other species, such as Labeo rohita, Catla catla, and Cirrhinus mrigala (Ahammad et al., 2003), Paralichthys olivaceus (Zhang et al., 2005), Piaractus mesopotamicus (Streit Jr. et al., 2007; Lopes et al., 2011, 2013), and Brycon orbignyanus (Paes, 2013).

We observed a linear decline in the percentage of viable larvae with an increase in cooling time. As for hatching rate, we must consider the percentage of viable larvae, action of the temperature, and period 
of contact with the cryoprotectant. Ferreira et al. (2017) concluded that larva survival is inversely proportional to storage time. The exposure of fish embryos to temperatures near $0{ }^{\circ} \mathrm{C}$ always reduces larva hatching rate, even when treated with protective solutions. Chao and Liao (2001) stated that there is a need to determine a balance between the efficiency of the cryoprotectant and the tolerance of embryos to the toxicity of that cryoprotectant.

Streit Jr. (2007) also observed a low percentage of viable larvae (less than 10\%) due to heat stress, even at intermediate temperatures of $5{ }^{\circ} \mathrm{C}$ and $-2{ }^{\circ} \mathrm{C}$. This sensitivity of fish embryos to cold is observed in many species (Pessoa et al., 2012; Oliveira-Araújo et al., 2016), such as Cyprinus carpio embryos, wherein temperatures of 0 and $4{ }^{\circ} \mathrm{C}$ led Dinnyés et al. (1998) to report a sensitivity to cold for this species. Zebrafish (Brachydanio rerio) embryos can tolerate temperature of $-15^{\circ} \mathrm{C}$ for up to $1 \mathrm{~h}$, but $3 \mathrm{~h}$ at this temperature becomes lethal, as noted by Zhang and Rawson (1995). Thus, a direct relationship between exposure time of curimba embryos at low temperature and the production of viable larvae is evidenced.

Sugars play an important role in the maintenance of osmotic pressure in cryoprotectant solutions (Holt, 2000). Woelders (1997) highlighted positive properties of sucrose when used with another non-permeating cryoprotectant. The addition of sucrose to cryoprotectant solutions has been used for studies of cooling of embryos of different species of fish, including curimba, with promising results (Zhang and Rawson, 1995; Ahammad et al., 1998; Ahammad et al., 2003; Streit Jr. et al., 2007; Costa et al., 2012; Ninhaus-Silveira et al., 2012; Lopes et al., 2013). The results observed in this study corroborate with these authors, since the use of $0.5 \mathrm{M}$ sucrose in the cryoprotectant solutions tested did not affect the variables analyzed.

According to some studies (Kusuda et al., 2002; Lopes et al., 2011; Pessoa et al., 2012; Oliveira-Araújo et al., 2016; Ferreira et al., 2017), the death of embryos when exposed to cryoprotectants is generally related to cellular degeneration and proteins of the nuclear membrane, due to dehydration and an increase in salt concentration with cryoprotectant contact. The toxicity of cryoprotectants to fish embryos has been confirmed by Urbányi et al. (1997), who considered it a significant issue in the development of techniques involving low temperatures.

\section{Conclusions}

High concentrations of permeable cryoprotectants (DMSO and methanol) and cooling time, greater than $4 \mathrm{~h}$ at $4{ }^{\circ} \mathrm{C}$, directly influence the hatching rate and the production of viable larvae.

\section{Conflict of Interest}

The authors declare no conflict of interest.

\section{Author Contributions}

Investigation: G.J. Machado, L.D.S. Murgas, P.C. Palhares, I.L. Assis and T.F.D. Castro. Methodology: G.J. Machado, L.D.S. Murgas, P.C. Palhares, I.L. Assis and T.F.D. Castro. Supervision: L.D.S. Murgas. Writing-original draft: G.J. Machado and L.D.S. Murgas. Writing-review \& editing: G.J. Machado and L.D.S. Murgas.

\section{Acknowledgments}

The authors would like to thank the Fundação de Amparo à Pesquisa do Estado de Minas Gerais (FAPEMIG), Conselho Nacional de Desenvolvimento Científico e Tecnológico (CNPq), and Coordenação de Aperfeiçoamento de Pessoal de Nível Superior (CAPES), for financial support; the Environmental Station of the Companhia Energética de Minas Gerais S.A. (CEMIG) in Itutinga, Minas Gerais, Brazil, for providing the fish and infrastructure; and the company Spark English, for translation services. 


\section{References}

Ahammad, M. M.; Bhattacharyya, D. and Jana, B. B. 1998. Effect of different concentrations of cryoprotectant and extender on the hatching of Indian major carp embryos (Labeo rohita, Catla catla, and Cirrhinus mrigala) stored at low temperature. Cryobiology 37:318-324. https://doi.org/10.1006/cryo.1998.2127

Ahammad, M. M.; Bhattacharyya, D. and Jana, B. B. 2003. Hatching of common carp (Cyprinus carpio L.) embryos stored at 4 and $2^{\circ} \mathrm{C}$ in different concentrations of ethanol and sucrose. Theriogenology 60:1409-1422.

Bart, A. N. and Kyaw, H. A. 2003. Survival of zebrafish, Brachydanio rerio (Hamilton-Buchanan), embryo after immersion in methanol and exposure to ultrasound with implications to ultrasound with implication to cryopreservation. Aquaculture Research 34:609-615. https://doi.org/10.1046/j.1365-2109.2003.00852.x

Cabrita, E.; Robles, V.; Chereguini, O.; Wallace, J. C. and Herráez, M. P. 2003. Effect of different cryoprotectants and vitrificant solutions on the hatching rate of turbot embryos (Scophthalmus maximus). Cryobiology 47:204-213. https://doi.org/10.1016/j.cryobiol.2003.10.001

Chao, N. H. and Liao, I. C. 2001. Cryopreservation of finfish and shellfish gametes and embryos. Aquaculture 197:161-189. https://doi.org/10.1016/S0044-8486(01)00586-5

Costa, R. S.; Souza, F. M. S.; Senhorini, J. A.; Ribeiro, D. C.; Bashiyo-Silva, C.; Coelho, G. C. Z.; Verissimo-Silveira, R. and NinhausSilveira, A. 2018. Improved solution for vitrification of Prochilodus lineatus embryos based on the reduction in risk factors: Toxicity, osmotic responses and ice-nucleation. Aquaculture Research 49:793-800. https://doi.org/10.1111/are.13510

Costa, R. S.; Souza, F. M. S.; Senhorini, J. A.; Veríssimo-Silveira, R. and Ninhaus-Silveira, A. 2017. Effects of cryoprotectants and low temperatures on hatching and abnormal embryo development of Prochilodus lineatus (Characiformes: Prochilodontidae). Neotropical Ichthyology 15(3):e170043. https://doi.org/10.1590/1982-0224-20170043

Costa, R. S.; Velardi, J.; Senhorini, J.; Veríssimo-Silveira, R. and Silveira, A. 2012. Resfriamento de embriões de peixes neotropicais. In: V AQUACIÊNCIA, Palmas-TO.

Dinnyés, A.; Urbányi, B.; Baranyai, B. and Magyary, I. 1998. Chilling sensitivity of carp (Cyprinus carpio) embryos at different developmental stages in the presence or absence of cryoprotectants: work in progress. Theriogenology 50:1-13. https://doi.org/10.1016/S0093-691X(98)00108-3

Ferreira, A. V. L.; Martins, M. F.; Sousa, M. L. N. M.; Soares Filho, A. A. and Sampaio C. M. S. 2017. Survival of Macrobrachium amazonicum embryos submitted to cooling. Zygote 25:288-295. https://doi.org/10.1017/S0967199417000119

Fornari, D. C.; Ribeiro, R. P.; Streit Jr, D. P.; Sirol, R. N.; Povh, J. A.; Carvalho, S. and Oliveira, D. 2008. Resfriamento de embriões de cascudo preto (Rhinelepis aspera) submetidos a diferentes ciroprotetores. In: Anais da 45a Reunião Anual da Sociedade Brasileira de Zootecnia. Sociedade Brasileira de Zootecnia, Lavras.

Fornari, D. C.; Streit Jr, D. P.; Tonissi, L. B.; Povh, J. A.; Sirol, R. N. and Ribeiro, R. P. 2014. Crioprotetores para o resfriamento de embriões de piracanjuba Brycon orbignyanus (Valenciennes, 1850). Semina: Ciências Agrárias 35:2809-2816.

Hagedorn, M.; Kleinhans, F. W.; Wildt, D. E. and Rall, W. F. 1997. Chill sensitivity and cryoprotectant permeability of dechorionated zebrafish embryos, Brachydanio rerio. Cryobiology 34:251-263. https://doi.org/10.1006/cryo.1997.2002

Henn, K. and Braunbeck, T. 2011. Dechorionation as a tool to improve the fish embryo toxicity test (FET) with the zebrafish (Danio rerio). Comparative Biochemistry and Physiology Part C: Toxicology \& Pharmacology 153:91-98. https://doi.org/10.1016/j.cbpc.2010.09.003

Holt, W. V. 2000. Basic aspects of frozen storage of semen. Animal Reproduction Science 62:3-22. https://doi.org/10.1016/S0378-4320(00)00152-4

Hubálek, Z. 2003. Protectants used in the cryopreservation of microorganisms. Cryobiology 46:205-229. https://doi.org/10.1016/S0011-2240(03)00046-4

Kais, B.; Schneider, K. E.; Keiter, S.; Henn, K.; Ackermann, C. and Braunbeck, T. 2013. DMSO modifies the permeability of the zebrafish (Danio rerio) chorion-implications for the fish embryo test (FET). Aquatic Toxicology 140-141:229-238. https://doi.org/10.1016/j.aquatox.2013.05.022

Kusuda, S.; Teranishi, T. and Koide, N. 2002. Cryopreservation of chum salmon blastomeres by the straw method. Cryobiology 45:60-67. https://doi.org/10.1016/S0011-2240(02)00106-2

Lopes, T. S.; Romagosa, E.; Streit Jr., D. P.; Ribeiro, R. P. and Digmayer, M. 2011. Cooling of pacu (Piaractus mesopotamicus) embryos at various stages of development for 6 or 10 hours. Theriogenology 75:570-576. https://doi.org/10.1016/j.theriogenology.2010.09.030

Lopes, T. S.; Streit Jr., D. P.; Fornari, D. C.; Oliveira, D.; Ribeiro, R. P.; Ribeiro, R. P. and Romagosa, E. 2013 Chilling curves for Piaractus mesopotamicus (Holmberg, 1887) embryos stored at $-8^{\circ} \mathrm{C}$. Zygote 21:345-350. https://doi.org/10.1017/S0967199412000020

Lopes, T. S.; Streit Junior, D. P.; Ribeiro, R. P. and Romagosa, E. 2014. Post-cooling damage to Piaractus mesopotamicus embryos at different stages of development. Atas de Saúde Ambiental-ASA 2:2-11.

R. Bras. Zootec., 48:e20160377, 2019 
Murgas, L. D. S.; Felizardo, V. O.; Ferreira, M. R.; Veras, G. C.; Andrade, E. S. and Paula, D. A. J. 2012. Eficiência reprodutiva em espécies nativas de peixes de água doce. Ciência Animal 22:197-206.

Ninhaus-Silveira, A. 2007. Preservação dos gametas de peixes e suas aplicações. Revista Colombiana de Ciências Pecuarias 20:516-517.

Ninhaus-Silveira, A.; Costa, R. S.; Velarde, J. M. C.; Senhorini, J.A. and Veríssimo-Silveira, R. 2012. Toxicidade de crioprotetores aos embriões de Prochilodus lineatus. In: AQUACIÊNCIA, Palmas-TO.

Oliveira-Araújo, M. S.; Salmito-Vanderley, C. S. B.; Almeira-Monteiro, P. S.; Lopes, J. T. and Leite-Castro, L. V. 2016. Dose inseminante e resfriamento de embriões de peixes de água doce. Revista Brasileira de Reprodução Animal 40:35-40.

Paes, M. C. F. 2013. Viabilidade de embriões de piracanjuba (Brycon orbignyanus) submetidos a diferentes protocolos de resfriamento. Tese (D.Sc.). Universidade Estadual Paulista, Jaboticabal.

Paes, M. C. F.; da Silva, R. C.; do Nascimento, N. F.; Valentin, F. N.; Senhorini, J. A. and Nakaghi, L. S. O. 2014. Hatching, survival and deformities of piracanjuba (Brycon orbignyanus) embryos subjected to different cooling protocols. Cryobiology 69:451-456. https://doi.org/10.1016/j.cryobiol.2014.10.003

Paula, D. A. J.; Machado, M. R. F.; Murgas, L. D. S.; Rabelo, D.; Zangerônimo, M. G.; Neto, R. V. R.; Andrade, E. S and Andrade, E. A. 2014. Toxicity on cryoprotectants on Prochilodus lineatus (Valenciennes, 1837) (curimba) embryos in an experimental incubator (Characiformes: Prochilodontidae). Neotropical Ichthyology 12:835-844. https://doi.org/10.1590/1982-0224-20130234

Pessoa, N. O.; Evangelista, J. S. A. M.; de Sousa Filho, F. G. M.; de Sousa, M. L. N. M.; Lourenço, A. V. and Sampaio, C. M. S. 2013. Resfriamento de embriões de tambaqui (Colossoma macropomum) em diferentes tempos de estocagem. Revista Brasileira de Higiene e Sanidade Animal 7:323-344.

Pessoa, N. O.; Galvão, J. A. S.; de Souza Filho, F. G. M.; de Sousa, M. L. N. M. and Sampaio, C. M. S. 2015. Cooling of pirapitinga (Piaractus brachypomus) embryos stored at $-10^{\circ} \mathrm{C}$. Zygote $23: 453-459$. https://doi.org/10.1017/S0967199414000057

Pessoa, N. O.; Sousa, M. L. N. M.; Evangelista, S. A. M.; Soares Filho, A. A. and Sampaio, C. M. S. 2012. Resfriamento e criopreservação de embriões de peixes. Ciência Animal 22:57-62.

Reis, R. E.; Kullandere, S. O. and Ferraris Jr, C. J. 2003. Check List of the Freshwater Fishes of South and Central America. Edipucrs, Porto Alegre. 729p.

Rizzo, E.; Godinho, H. P. and Sato, Y. 2003. Short-term storage of oocytes from the neotropical teleost fish Prochilodus marggravii. Theriogenology 60:1059-1070. https://doi.org/10.1016/S0093-691X(03)00108-0

Streit Jr., D. P.; Ribeiro, R. P.; Sirol, R. N.; Moraes, G. V. D.; Oliveira, C.; Mora, F. P. and Lupichinski, E. 2007. Conservação de embriões de pacu. In: Congresso Brasileiro de Produção de Peixes Nativos de Água Doce. Dourados-MS.

Urbányi, B.; Baranyai, B.; Magyary, I. and Dinnyes, A. 1997. Toxicity of methanol, DMSO and glycerol on carp (Cyprinus carpio) embryos in different developmental stages. Theriogenology 47:408. https://doi.org/10.1016/S0093691X(97)82535-6

Woelders, H. 1997. Fundamentals and recent development in cryopreservation of bull and boar semen. The Veterinary Quarterly 19:135-138. https://doi.org/10.1080/01652176.1997.9694758

Woynarovich, E. and Horváth, L. 1989. Propagação artificial de peixes de águas tropicais: manual de extensão. FAO/CODEVASF/CNPQ Brasília.

Zhang, T. and Rawson, D. M. 1995. Studies on chilling sensitivity of zebrafish (Brachydanio rerio) embryos. Cryobiology 32:239-246. https://doi.org/10.1006/cryo.1995.1023

Zhang, Y. Z.; Zang, S. C.; Liu, X. Z.; Xu, Y. J.; Hu, J. H.; Xu, Y. Y.; Li, J. and Chen, S. L. 2005. Toxicity and protective efficiency of cryoprotectants to flounder (Paralichthys olivaceus) embryos. Theriogenology 63:763-773. https://doi.org/10.1016/j.theriogenology.2004.04.011

Zaniboni-Filho, E. and Baldisserotto, B. 2015. Congelação de sêmen e tecidos de peixes brasileiros. Revista Brasileira de Reprodução Animal 39:189-194. 